\title{
Intermédialités
}

Histoire et théorie des arts, des lettres et des techniques

Intermediality

History and Theory of the Arts, Literature and Technologies

\section{Fototopografia: The "Futures Past” of Surveying}

\section{Jan von Brevern}

Numéro 17, printemps 2011

reproduire

reproducing

URI : https://id.erudit.org/iderudit/1005748ar

DOI : https://doi.org/10.7202/1005748ar

Aller au sommaire du numéro

Éditeur(s)

Revue intermédialités (Presses de l’Université de Montréal)

ISSN

1705-8546 (imprimé)

1920-3136 (numérique)

Découvrir la revue

Citer cet article

von Brevern, J. (2011). Fototopografia: The "Futures Past" of Surveying.

Intermédialités / Intermediality, (17), 53-67. https://doi.org/10.7202/1005748ar

\section{Résumé de l'article}

Dans cet article, l'auteur s'intéresse à un problème qui remonte aux débuts de l'utilisation de la photographie pour les relevés de terrain. Il s'agit de l'inébranlable désir d'utiliser la photographie pour saisir des informations topographiques précises, à des fins de cartographie, et ceci malgré les difficultés pratiques. Il montre comment le travail de relevé a changé en même temps que le statut de la photographie : je situe ce changement au moment où l'on arrête de mesurer le terrain et où les mesures se font sur les images photographiques elles-mêmes. Depuis ses tout débuts, la photographie promettait de simplifier l'épuisant travail mené sur le terrain. Mais dans la pratique, il fallut des décennies d'expérimentation avant que la promesse se réalise. 


\title{
Fototopografia: \\ The "Futures Past" of Surveying
}

\author{
JAN VON BREVERN
}

n the summer of 1878, Italian engineer Pio Paganini led a photographic survey campaign in the "Alpi Apuane," a part of the Apennines, close to Carrara in Tuscany. For many years, members of the Istituto Topografico Militare in Florence had been testing and discussing how photography could facilitate the tedious work of topographical surveying in difficult terrain such as mountains. ${ }^{1}$ The task seemed easy enough. As the ever-increasing number of photo studios across Italy seemed to suggest, anyone was able, after all, to take photographs. "L'arte del fotografo non è arte difficile," Capitano Michele Manzi had confidently declared in 1875. He was convinced "without reticence" that photography would soon be suitable for major military and topographical applications. ${ }^{2}$ Paganini set out to prove that an exact map could indeed be deduced from photographic images. Equipped with dry plates of the latest kind and a newly designed camera, called fototeodolite, he and his team took over a hundred pictures from different viewpoints, uniting them later to form seventeen panoramas. One of them is the panorama taken from Cima del Monte (Fig. 1). It consists of six single images, covering a horizon of roughly 200 degrees.

1. The Istituto Topografico Militare was renamed Istituto Geografico Militare (I.G.M) in 1885 . Its early endeavours in "fototopografia" have been documented in a manuscript stored today in the archives of the I.G.M.: Relazione del Magg.re Rosalba su gli studi di fotografia eseguiti nell'Istituto dal 1875 al 1881 (manoscritto), Florence, 1881. Already before 1863, Maggiore Ignazio Porro had worked on the application of photography in geodesy, but his attempts were not continued. See Ignazio Porro, "Applicazione della fotografia alla geodesia," Il Politecnico. Giornale dell'ingegnere, architetto ed agronomo, vol. 11, 1863, p. 708-709. Much of my information about the earliest photographic activities of the I.G.M. stems from an article that Stefano Caciolli of the institute's library was kind enough to share with me: Stefano Caciolli, "L'Istituto Geografico Militare di Firenze e la fotografia," AFT. Rivista di Storia e Fotografia, vol. 14, n² 28, 1998, p. 53-63.

2. Michele Manzi in Relazione Rosalba, 1881, p. 15-18. 


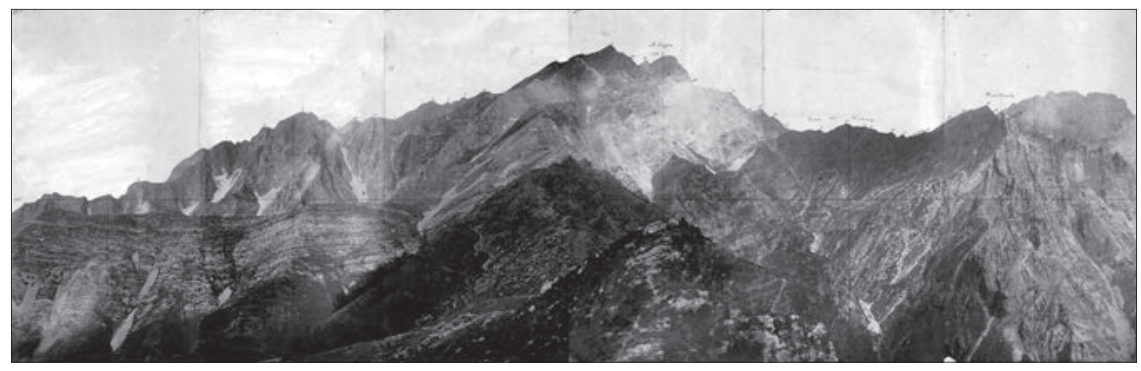

Fig. 1: Pio Paganini, Rilievo delle cave di Colonnata, AlpiApuane, Panorama VII, 1878. Istituto Geografico Militare, Florence.

Today, the indubitable aesthetic appeal of this panorama, which it possesses despite its technical nature, seems due, not only to the impressive mountain landscape, but also to the signs of age which it bears: a brownish tint, a rather low contrast, some stains and smears, as well as title, date and signature in an oldfashioned handwriting on the lower right corner of the cardboard. Alois Riegl, the Viennese art historian of the turn of the century whose interest famously extended to all kinds of ancient objects, would have called it the "Alterswert" - a certain cultural value which is inherent to visible signs of deterioration and which turns artefacts into monuments, regardless of their intended purpose. As a result, the panorama, more than representing a landscape, seems to capture an ancient gaze at this landscape. After more careful observation, however, Paganini's panorama also reveals traces of what Riegl would have called its "historic value"traces of its former function which make it a representation of "a very particular, individual stage of development of a certain productive realm of mankind." ${ }^{\prime 3}$ In this case, it is two very thin lines crossing at the centre of every single picture, and a number of figures in red and blue ink scattered all over the panorama which allow us to reconstruct the procedures and status of early photogrammetry. The lines stem from two silver wires attached to the inside of the fototeodolite (Fig. 2), indicating the horizontal and vertical axes of the photos. As we will see shortly, this simple device was essential for the whole process of photogrammetry. The figures, on the other hand, specify terrain points that were to be identified on at least two different panoramas and would later constitute the basis for the topographical map.

3. "Der historische Wert eines Denkmals ruht darin, daß es uns eine ganz bestimmte, gleichsam individuelle Stufe der Entwicklung irgendeines Schaffensgebietes der Menschheit repräsentiert," in Alois Riegl, "Der moderne Denkmalkultus, sein Wesen, seine Entstehung," in Gesammelte Aufsätze, Augsburg and Vienna, Filser Verlag, 1928, p. 144-193. 


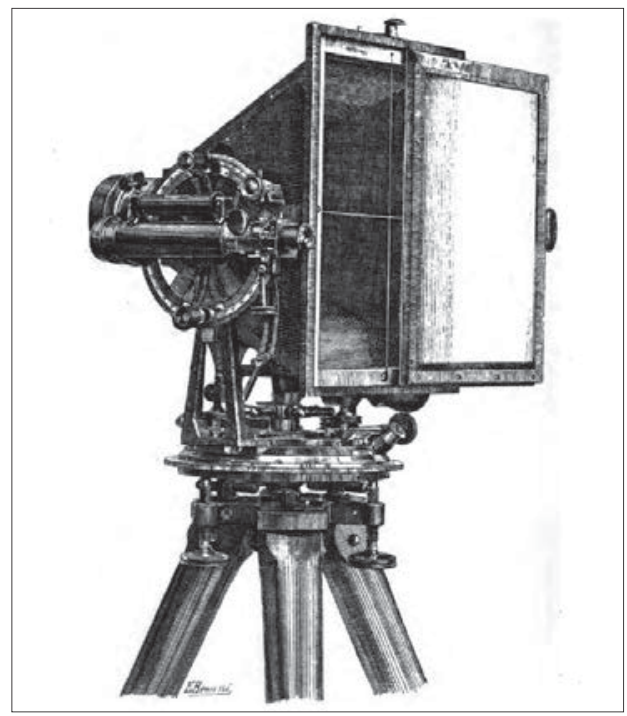

Fig. 2: Aparecchiofototopografico. Pio Paganini, La Fototopografia in Italia, Rome, Civelli, 1889, p. 8-9.

The main challenge of early photogrammetry was to extract the desired topographical information from the photographs and to transfer it into technical drawings, which, in a further step, were used to draw maps. The advantages of this technique were obvious: photographic field workers would take the pictures within a few hours, while the more complicated and time consuming graphical work and calculation could be done later at the office. In 1878, Paganini still had to explain the new survey technique and its benefits: "While Topography proposes to determine the terrain forms from elements within the terrain itself, Fototopografia proposes to obtain the same result by extracting these terrain elements from special photographs." Photography's promise to be able to do this was almost as old as photography itself-but, in practice, it took decades of experimenting until the process was feasible. It demanded new professions and skills as much as new technologies. ${ }^{5}$ As I will argue, this substitution was rather

4. "Nel mentre la Topografia si propone di determinare la forma del terreno ricavandone gli elementi sul terreno stesso, la Fototopografia si propone di ottenere lo stesso risultato ricavandone gli elementi della forma del terreno, da speciali representazioni fotografiche dello stesso." Pio Paganini in Relazione Rosalba, 1881, p. 86 (my translation).

5. On the theory and history of photogrammetry, see Teodor J. Blachut and Rudolf Burkhardt, Historical Development of Photogrammetric Methods and Instruments, Falls Church, American Society for Photogrammetry and Remote Sensing, 1988. See also K. B. Atkinson, "Deville and Photographic Surveying," Photogrammetric Record, vol. 86, 
momentous for the epistemology of photography. But it also implied a fundamental shift in land surveying. Photogrammetry was, as a later handbook put it, "topography without topographers."

\section{FORM, DIVORCED FROM MATTER}

When Paganini led his campaign in 1878 , photogrammetry already had, as he pointed out, a history that could have filled a whole book. A decade earlier, in May 1865, the German construction engineer Albrecht Meydenbauer had presented a series of technical drawings of buildings at the first photographic exhibition in Berlin. They were transcribed from photographs that he himself had made. Photometrographie, as he then still called photogrammetry, promised to make the tedious work of architectural surveying easier and more precise at the same time. ${ }^{7}$ Meydenbauer's plans and front views demonstrated that it was indeed possible to reconstruct the dimensions of a given building from photographs. Walking through the exhibition halls and looking at the other works, a sudden thought occurred to him: "Among the pictures of this exhibition," Meydenbauer noted, "were two very beautiful Alpine landscapes, and by chance the author caught sight of an immense mountain with inaccessible peaks and snowfields on two different, adjacent photographs. Only by this sight did it become clear to the author in a single moment-in a flash-that photogrammetry could be used for

n ${ }^{\circ}$ 15, 1995, p. 189-195. Michael Ponstingl, "Der Soldat benötigt sowohl Pläne als auch Karten. Fotografische Einsätze im k. (u.) k. Militärgeographischen Institut zu Wien, Teil II," Fotogeschichte, vol. 22, n 83, 2002, p. 53-82. Herta Wolf, "Das Denkmälerarchiv Fotografie," in Diskurse der Fotografie. Fotokritik am Ende des fotografischen Zeitalters, Frankfurt, Suhrkamp, 2003, p. 349-375. Peter Geimer, "Bild und Zahl. Zur Typologie fotografischer Bilder," in Thomas Hensel and Andreas Koestler (eds.), Einführung in die Kunstwissenschaft, Berlin, Reimer, 2004, p. 157-177. Stefan Siemer, "Bildgelehrte Geotechniker. Luftbild und Kartographie," in Alexander Gall (ed.), Konstruieren, Kommunizieren, Präsentieren. Bilder von Wissenschaft und Technik, Göttingen, Wallstein, 2007, p. 69-108. For older, but nonetheless thorough accounts, see Aimé Laussedat, Recherches sur les instruments, les méthodes et le dessin topographique, Paris, Gauthier-Villars, 19o1. See also Max Weiß, Die geschichtliche Entwicklung der Photogrammetrie und die Begründung ihrer Verwendbarkeit für Meß-und Konstruktionszwecke, Stuttgart, Strecker \& Schröder, 1913.

6. Félix Ollivier, La topographie sans topographes. Traité de photogrammétrie, Paris, Éditions de la Revue d'optique théorique et instrumentale, 1929.

7. The word "Photogrammetrie" was first used by Meydenbauer in 1867: Albrecht Meydenbauer, "Ueber die Anwendung der Photographie zur Architektur- und TerrainAufnahme," Zeitschrift für Bauwesen vol. 17, 1867, p. 61-70. 
the survey of any given object." ${ }^{\prime}$ Thus, as legend has it, the application of photography for land surveying purposes was born from unexpected circumstances.

Meydenbauer told this anecdote in retrospect, almost half a century later, in an attempt to present himself as the founder of photo-topography. This was certainly only partly true. Military officials in a number of countries had been working in this field for many years. In Italy, Maggiore Ignazio Porro had published an account of his attempts in $1863 .{ }^{9}$ But it was mainly in France that efforts to use photography in survey work had been made from the early 1850 on onward. Colonel Aimé Laussedat, later called the "father of photogrammetry," had first tried to substitute the plane table with the camera lucida, and subsequently with a photographic camera. ${ }^{10}$ In 1864 , he presented the Académie des Sciences in Paris with a topographical map of the surroundings of Grenoble, constructed exclusively after photographs. ${ }^{11}$ Laussedat's success inspired proponents of photography all over Europe and North America. ${ }^{12}$ Meydenbauer was only one of them-but a very successful one at that. With the Prussian Messbildarchiv, he later went on to establish one of the largest photographic archives of monuments, which still exists today. ${ }^{13}$

One element in particular is remarkable about Meydenbauer's story. It suggests that photogrammetry did not have to be invented, but was rather discovered-for it was just an application of some of the very principles that lay at the core of photography. The two photos Meydenbauer saw at the Berlin exhibition were landscapes, produced with no intention to be measurable. But because all photographs were "subject to the rules of geometry" and supposedly rendered every object with "mathematical precision," as François Arago and Joseph GayLussac had already established in 1839 , these landscapes were potential survey

8. Albrecht Meydenbauer, Handbuch der Messbildkunst in Anwendung auf Baudenkmäler-und Reise-Aufnahmen, Halle, Knapp, 1912, p. 9.

9. Porro, 1863 .

10. Aimé Laussedat, "Mémoire sur l'emploi de la chambre claire dans les reconnaissances topographiques," Mémorial de l'officier du génie, vol. 16, 1854. See also Aimé Laussedat, "Mémoire sur l'emploi de la photographie dans la levée des plans; par M. Laussedat (Extrait par l'auteur)," Comptes rendus des séances de l'Académie des Sciences, vol. 49, 1859, p. 732-734. For Laussedat's role in photogrammetry, see Josef Maria Eder, Geschichte der Photographie, Halle, Knapp, 1932, p. 557.

11. J. Bornecque, La photographie appliquée au lever des plans, Paris, Librairie Militaire de L. Baudoin et $\mathrm{C}^{\mathrm{ie}}, 1885$, p. 9.

12. For an example of the work of Deville in Canada, see Atkinson, 1995.

13. See Wolf, 2003. 
images as well. ${ }^{14}$ The opposite was true as well: Timothy O'Sullivan's survey images of the American West-to name just one example-later became icons of "artful" landscape photography. ${ }^{15}$ It was a common and telling conviction that "photogrammetry is as old as photography itself." ${ }^{16}$ In theory, though not in practice, as many operators were to find out, any photographic image could be used for photogrammetry.

As we have seen, the notion that real objects or landscapes could be replaced by their photographic images was central to the whole concept of photogrammetry. It was perhaps most radically expressed when Oliver Wendell Holmes, editor of The Atlantic Monthly, stated in 1859 that the most significant feature of photography was that it "divorced" form from matter: "In fact, matter as a visible object is of no great use any longer, except as the mould on which form is shaped." And quite polemically he added: "Give us a few negatives of a thing worth seeing, taken from different points of view, and that is all we want of it. Pull it down or burn it up, if you please."17 From the very beginning, the substitution of objects with images had the potential of construction as well as destruction. Military applications of photogrammetry in the $20^{\text {th }}$ century made wide use of the latter. ${ }^{18}$

Nevertheless, there was also an epistemological potential in this substitution. It was based on the often-noted effect that photography recorded details that the human eye missed-something that the earliest advocates of photography, like Henry Fox Talbot, had never failed to point out. Similarly, Meydenbauer declared: "It may seem incredible for some, but it has been affirmed by experience: you do

14. These quotes from Arago and Gay-Lussac can be found in almost every account of photogrammetry in the $19^{\text {th }}$ and $20^{\text {th }}$ centuries.

15. For a critique, see Rosalind Krauss, "Photography's Discursive Spaces: Landscape/ View," Art Journal, vol. 42, n ${ }^{\circ} 4$, 1982, p. 311-319. See also Joel Snyder, American Frontiers. The Photographs of Timothy H. O'Sullivan, 1867-1874, Millterton, Aperture, 1981, and Robin Earle Kelsey, Archive Style. Photographs \&. Illustrations for U.S. Surveys, 1850-189o, Berkeley, University of California Press, 2007.

16. "Die Photogrammetrie oder Bildmesskunst ist eben so alt wie die Photographie selbst." Carl Koppe, Die Photogrammetrie oder Bildmesskunst, Weimar, Verlag der Deutschen Photographen-Zeitung, 1889, p. V (my translation).

17. Oliver Wendell Holmes, "The stereoscope and the stereograph,"in Atlantic Monthly, vol. 3, n' 20, 1859, p. 738-748.

18. See Harun Farocki, "Die Wirklichkeit hätte zu beginnen," in Bernd Busch, Udo Liebelt, and Werner Oeder (eds.), Fotovision: Projekt Fotografie nach 150 Jahren, Hannover, Sprengel Museum, 1988, p. 119-125. See also Friedrich Kittler, Optische Medien. Berliner Vorlesung 1999, Berlin, Merve, 2002. 
not see everything, but many things better on the images than on site."19 In topographical terms, this meant that photographs contained an indefinite number of projection rays and therefore of potential terrain points. Which points were to be used did not have to be decided on the spot, but could be determined later while comparing the survey photographs.

Bound by linear perspective, photography turned huge mountain landscapes and rock formations into flat and manageable images that were "optically consistent." ${ }^{\text {20 }}$ Bruno Latour, borrowing the term from William Ivins, has stressed the importance of this quality of images for scientific work: "In linear perspective, no matter from what distance and angle an object is seen, it is always possible to transfer it-to translate it-and to obtain the same object at a different size as seen from another position." ${ }^{21}$ For Latour, it is crucial that the internal properties of the represented object are unmodified by this translation. In this way, objects become mobile in time and space: they can be carried away, scaled, compared, and combined. ${ }^{22}$

This was exactly what Laussedat, Meydenbauer, Paganini, and their colleagues were aiming for when they began to use photography for purposes of land surveying. However, taking photographs was but one intermediate step in photogrammetry. Photography still had to find its place among the complicated processes of mapmaking: "[...]photography will be the means and not the end," Capitano Manzi summarized photography's new and humble role. ${ }^{23}$ After the negatives were developed, the prints combined to panoramas and the different panoramas spread in the I.G.M.'s office, the real work would only begin. The final products were always plans, sections, or maps. As soon as the relevant data

19. "Es ist vielleicht für manchen unglaublich, aber durch Erfahrung festgestellt; man sieht nicht alles, aber vieles im Meßbilde besser als am Orte." Albrecht Meydenbauer, Das Denkmäler-Archiv. Ein Rückblick zum zwanzigiährigen Bestehen der Königlichen Messbild-Anstalt in Berlin, Berlin, Königliche Preußische Messbildanstalt, 1905, p. 18 (emphasis in the original text, my translation). For a discussion of this phenomenon, see Geimer, 2004. See also Farocki, 1988.

20. See William Ivins, On the Rationalization of Sight [1938], New York, Da Capo Press, 1973, p. 9 .

21. See Bruno Latour, "Drawing Things Together," in Michael Lynch and Steve Woolgar (eds.), Representation in Scientific Practice, Cambridge (Mass.) and London, MIT Press, 1988, p. 27.

22. See ibid., p. 19-68.

23. "[...] la fotografia sará mezzo e non fine." Relazione Rosalba, 1881, p. 18 (my translation). 
had been extracted from the photographs and translated into other media, they became downright useless - which is why Meydenbauer presented drawings at the Berlin exhibition, and not photographs. Therefore, the main concern of all efforts regarding photogrammetry, and the point where most problems occurred, was always the synchronization of the different imaging techniques involved. Not only did immense mountain landscapes have to be turned into relatively small photographs, but these photographs also had to be turned into topographical data. To put it in today's terms: the task was to mobilize the photographic referent. As it turned out, photogrammetry would not only revolutionize land surveying, it would also thoroughly change the status of the photographic image.

Considering how early its basic parameters were formulated, it is remarkable how long photogrammetry's capacity to mobilize the photographic referent existed only as a promise. For almost half a century, the final breakthrough seemed just a step away. Looking back at this epoch, it is most striking that in spite of multiple setbacks and problems, the confidence in photogrammetry's potentials remained unshaken.

In fact, there was widespread consensus that photogrammetry would be incredibly useful for cartographers, geologists and reconnaissance missions in the near future. Still, a few problems remained yet to be solved. "Actuellement, les difficultés [...] n'existent plus au même degré, et elles tendent de jour en jour à s'aplanir," Laussedat declared in $1859 .{ }^{24}$ Indeed, the theoretical simplicity of the whole procedure, which appeared just as a plain application of photography's natural qualities, seemed to justify such optimism. Fifteen years and many attempts later, the difficulties had only multiplied, but optimism prevailed. In his 1874 treatise, Gaston Tissandier stated that the application of photography to mapmaking was indeed "very close to be realised in a complete way." Tellingly, the topic of photographic surveying was located in the last chapter of his book, titled L'avenir de la photographie. ${ }^{25}$

Meanwhile, in Germany, the famous geodesist Wilhelm Jordan reassured his readers "[that the fact that] photogrammetry could be used with extraordinary

24. Laussedat, 1859 , p. 734 .

25. "L'application de la photographie au lever des plans militaires [...] est bien près d'être réalisée d'une façon complète." Gaston Tissandier, Les merveilles de la photographie, Paris, Hachette, 1874 , p. 302. 
advantage in many particular cases $[\ldots]$ seem[ed] at first sight to be beyond doubt." ${ }^{26}$ Jordan had taken part in an expedition to Libya, where he had led a photographic survey of the Gassr-Dachel oasis. The outcomes were described as encouraging. Still, photogrammetry remained in the experimental stagesfar too experimental, surely, to become part of the growing array of standard survey techniques. Even though Jordan was one of photogrammetry's fiercest promoters, he did not include or mention it in his authoritative Handbuch der Vermessungskunde. ${ }^{27}$ In the contemporary Mayers Konversations-Lexikon, it is noted that the Prussian General Staff made several attempts to implement the new survey technique but, for the present, refrained from using it because, compared to the common measuring methods, a facilitation of work and a greater precision did not occur. One of the problems that was mentioned in the encyclopaedia was "the very difficult mode of drawing after photographs"-indeed the pivotal point of early photogrammetry. ${ }^{28}$

By that time, the fact that such a powerful technique failed to be utilized seems to have made some experts nervous. In particular German topographers found it irritating that in other countries photogrammetry had made considerable progress. The Munich-based geodesist Sebastian Finsterwalder remarked in 1890 that in Italy, thousands of square kilometres of alpine territory had already been photographically surveyed - with hardly anyone taking notice in Germany. What astonished Finsterwalder most was the skill with which the topographers of the I.G.M. transformed the photos into maps. Anyone with an interest in mapmaking "will absorb himself with greatest pleasure into the many details of this map and will never stop to admire the accuracy and fidelity with which everything is overheard from nature." ${ }^{29}$

26. "Dass die Photogrammetrie in vielen gewissen Fällen mit außerordentlichem Vorteil angewendet werden könnte, z.B. bei schwer zugänglichen Gebirgen und auf Entdeckungsreisen, erscheint beim ersten Blick auf die Sache zweifellos." Wilhelm Jordan, "Ueber die Verwerthung der Photographie zu geometrischen Aufnahmen (Photogrammetrie)”, Zeitschrift für Vermessungswesen, vol. 5, nº 1, 1876, p. 1-17 (my emphasis, my translation).

27. Wilhelm Jordan, Handbuch der Vermessungskunde, Stuttgart, Metzler, 1888.

28. Mayers Konversations-Lexikon, vol. 13, Leipzig, Bibliographisches Institut, 18851890, p. 16.

29. “[...] Der wird sich mit größtem Genusse in die Betrachtung des mannigfachen Details dieser Karte versenken und nie aufhören, die Sorgfalt und Treue zu bewundern, mit der Alles der Natur abgelauscht ist." Sebastian Finsterwalder, "Die Photogrammetrie 


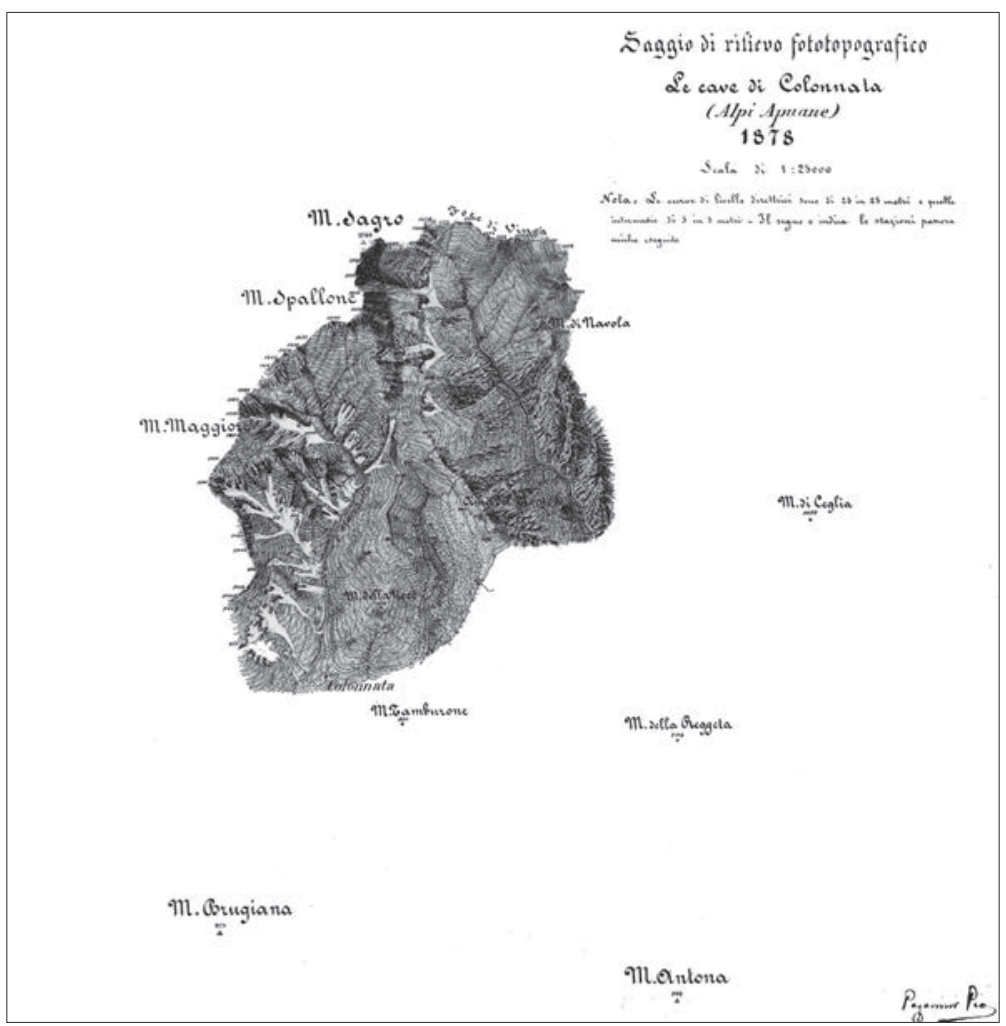

Fig. 3: Saggio di rilievo fototopografico: Le cave di Colonnata, 1878. Istituto Geografico Militare, Florence.

Today, we can reconstruct how Italian engineers managed to mobilize the photographic referent by following the path from the panorama (Fig. 1) to the small map (Fig. 3) that was the outcome of Paganini's campaign in the Apennines in 1878. Fototopografia consisted of several individual yet intertwined steps, as Paganini explained at greater length in a later publication. ${ }^{30}$ At first, the viewpoints for the camera had to be chosen. This was a crucial decision. For a detailed map, it was necessary that as many key terrain points as possible were visible at least on two, still better three, different panoramas. Ideally, those viewpoints were already established points in the trigonometric network. If not, they had to be positioned by resection. Then, the photographic work began. The operator had to orientate his instrument, using auxiliary devices like theodolite and level. The

in den italienischen Hochalpen," Mittheilungen des Deutschen und Oesterreichischen Alpenvereins, vol. 16, $\mathrm{n}^{\circ}$ 1, 1890, p. 6-9 (my translation).

30. Pio Paganini, La fototopografia in Italia, Rome, Civelli, 1889. 


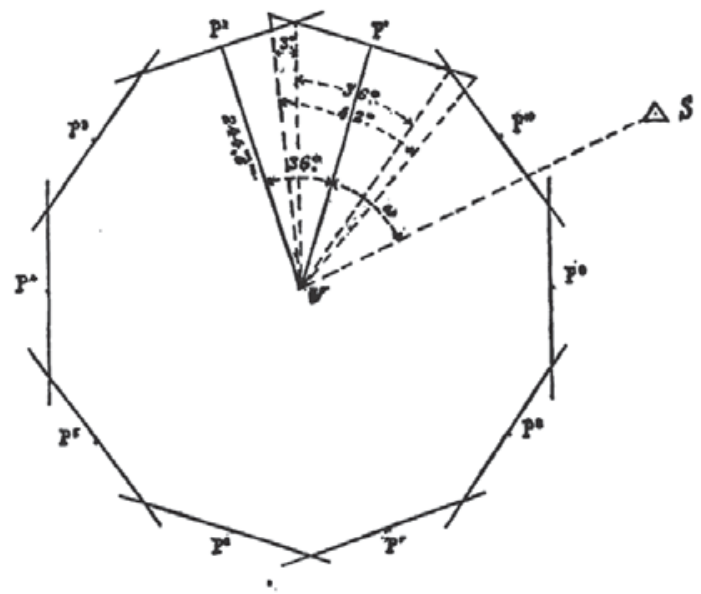

Fig. 4: Panoramic polygon. Pio Paganini, La Fototopografia in Italia, Rome, Civelli, 1889, p.14.

camera was then turned on the tripod to circle the horizon. In Paganini's system, ten photographs made a complete panorama (Fig. 4). Needless to say, all these operations had to be executed with the utmost precision, because the smallest deviance at this stage could lead to a failure of the whole campaign. Also needless to say, these operations took place in difficult conditions: wind, rain, clouds, as well as the movement of the sun and changing light conditions often rendered the images useless, requiring field workers to return to the mountaintop.

When good images had been obtained, the office work, and thus the proper photogrammetric processing, could start. The pictures were combined into panoramas, and survey engineers tried to identify as many homologous image points as possible. After they had been identified, the points were assigned a position on the horizontal and vertical axes using the thin wire lines on the photographs (Fig. 5). Then, a graphic representation of all the relevant panoramas was laid out, true to scale, on another sheet of paper (Fig. 6). Through simple intersections, the terrain points could now be determined on this sheet. Finally, out of these terrain points, and again with the help of the panoramas, a detailed map with contour lines was drawn.

Of course, this was an ideal workflow. As with every other kind of topographical survey work, error calculation was almost inevitable. In addition to known problems of trigonometrical surveying, such as refraction and earth curvature, many new sources of error were introduced by photography. One of them was the quality of the lenses; due to chromatic aberrations and optical distortions, real 


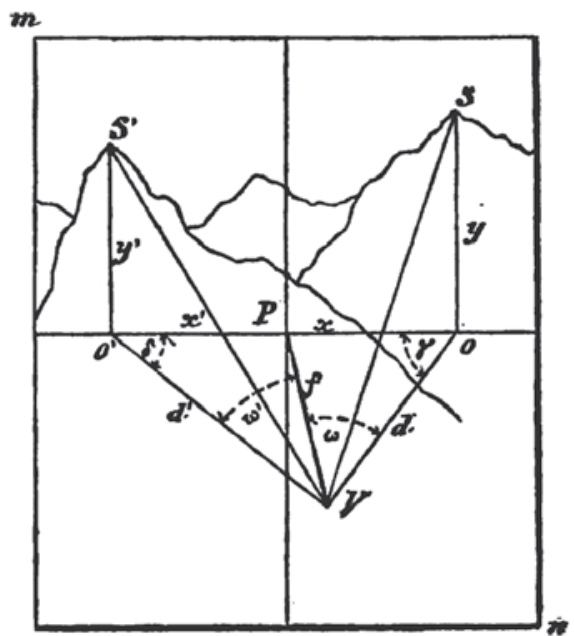

Fig. 5: Geometric extraction of terrain points with horizontal and vertical axes. Pio Paganini, La Fototopografia in Italia, Rome, Civelli, 1889 , p. 19.

photographic images were far from "mathematical precision." Only technical progress in lens making would minimize this problem over the years.

However, the step that represented a great source of despair for many early proponents of photogrammetry was the identification of the same terrain points on different photographs. Most of the time, it seemed impossible to say with certitude if a certain rock, protrusion or crack visible in one image was identical with one in a second image, taken from a different angle. More than anything, this task required experience and a trained eye. ${ }^{31}$

Looking at a photogrammetric image had little to do with looking at a regular photo. Standard conventions of landscape aesthetics like composition, aerial perspective, or chiaroscuro - all habitually applied by landscape photographers since the 1850 - played no role whatsoever in photogrammetry. Whatever aesthetic qualities contemporaries might have seen in photogrammetric imagesthey were merely the "waste products" of purely utilitarian aims: measurability, precision, comparability. As a result, trained personnel that could adapt to the new ways of seeing and drawing were the crux of early photogrammetry. When Carl Koppe published Die Photogrammetrie oder Bildmesskunst in 1889, he did

31. See Ponstingl, 2002. This problem was only solved after the turn of the century with the introduction of stereo photogrammetry, which made it possible to automate image analysis. One such early device was "Pulfrich's Stereokomparator," see Weiß, 1913, p. 21. 


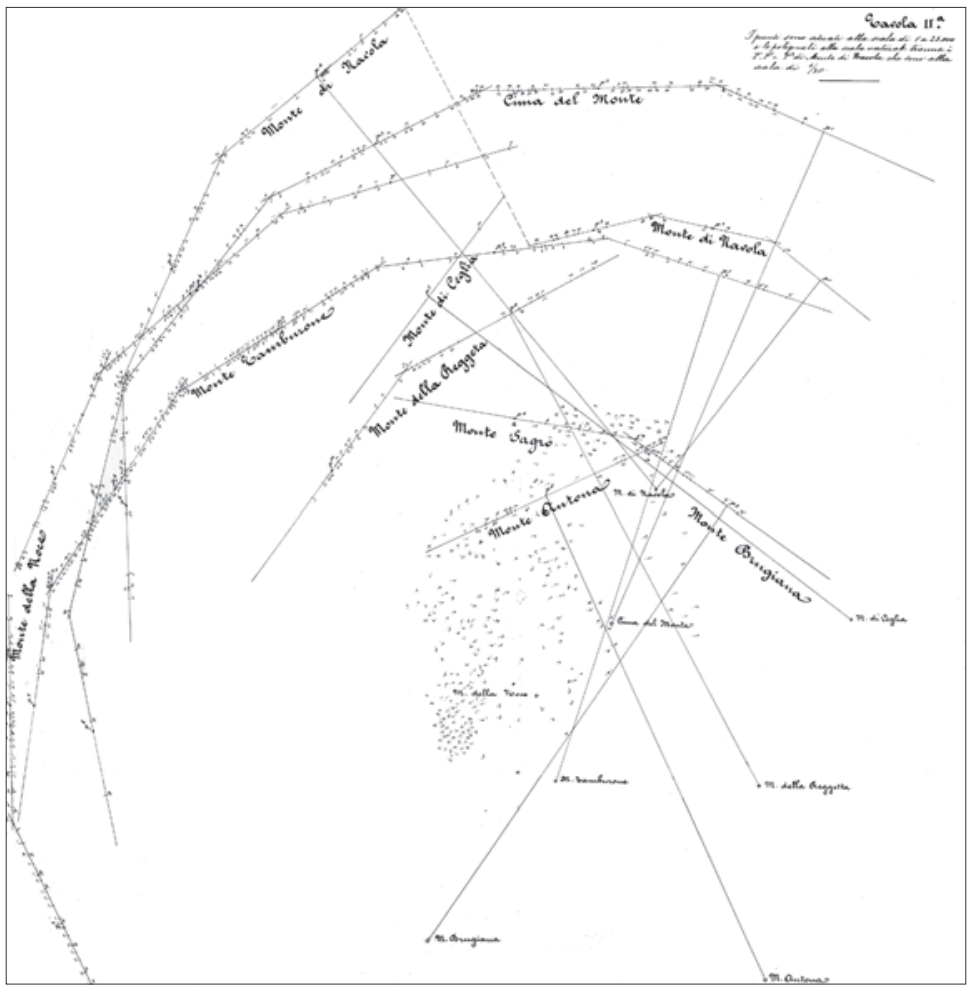

Fig. 6: Graphic representation of several panoramas of the area around the Cave di Colonnata, 1878. Istituto Geografico Militare, Florence.

not doubt that the new technique would be very successful in the near future when he wrote: "the only thing that is still missing is appropriately skilled personnel." 32 The mobilizing of the photographic referent required not only new images, but also a new kind of viewer and draughtsman.

As enthusiastic as German topographers were about the progress of photogrammetry in Italy, even there it long remained a technology in the future tense. The outcome of Paganini's 1878 campaign, for example (Fig. 3), may have constituted a good map in and of itself. But its aim was not so much to represent a part of the Apennines that could be used for military or other purposes. Instead

32. [I]ch bin überzeugt [...], dass topographische Aufnahmen, Vorarbeiten für technische Projecte etc. im Hochgebirge mit Hilfe der Photogrammetrie in einer Vollständigkeit ausgeführt werden können, wie sie keine andere Vermessungsmethode zu liefern im Stande ist. Es fehlt nur noch ein entsprechend ausgebildetes Personal." Koppe, 1889, p. VII (my translation). 
it was, more than anything else, the vital proof that such a representation was even made possible by photographic means. Accordingly, it was titled Saggio di rilievo fototopografico-a "sample" of photogrammetric survey work that was to convince military officials of the advantages and the practicability of the new technique. Commenting on his own map, Paganini hazarded one of the many prophecies in the history of photogrammetry: "I predict that from now on, this survey method will be the preferred one for difficult terrains," he wrote after his return from the photographic campaign in the Apennines. ${ }^{33}$

\section{FUTURES PAST}

One characteristic of photogrammetry in particular presented a great challenge to the status of the photographic image: the fact that the photographic referent was no longer located within a single image. Instead, as we have seen, it came into being during the transformation process. Only when a certain terrain point could be identified on two or more panoramas a reference to the outside world was established. And only if these points could be transferred into drawings and brought into relation with many other points was this reference stabilized. "It is important to understand that a bare image has no referent," Latour once remarked. ${ }^{34}$ Here, reference is described as something that is produced through a whole "cascade" of inscriptions (images, maps, graphs, diagrams etc.). ${ }^{35}$ This is what Manzi gestured toward when he stated that, in fototopografia, the photographs were "means and not ends." The early history of photogrammetry, then, provides us with a case study of the difficult task of aligning photography and drawing in such way that a rough landscape would finally be transformed into a usable map.

Throughout decades of experimentation, Paganini and others seem to have been driven by photography's promise to produce mathematically precise images. The early statements of Arago and others about the potential qualities of photography were to become self-fulfilling prophecies. But in 1878, when Paganini campaigned in the Apennines, the future of fototopografia seemed to have only just begun.

33. "Prevedo fin d'ora che questo metodo di rilievo sará il preferito per terreni difficili." Relazione Rosalba, 1881, p. 87 (my translation).

34. Bruno Latour, "Arbeit mit Bildern oder: Die Umverteilung der wissenschaftlichen Intelligenz," in Der Berliner Schlïssel. Erkundungen eines Liebhabers der Wissenschaften, Berlin, Akademie, 1996, p. 183.

35. See Latour, 1988, p. 40. 
Taking another look at the panorama (Fig. 1), we now recognize a third kind of value added to the two already defined by Riegl. The image does not only have an Alterswert, which may inspire a certain nostalgia, and a historischer Wert, which allows us to reconstruct a particular realm of past culture. It also contains something that we may call Vergangene Zukunft or futures past, a term coined by the historian Reinhart Koselleck. ${ }^{36}$ Sure enough, the panorama was used for survey work; a fact that is verified by the numbered blue and red ink dots. But to us today, the panorama also represents a document of hopes and potentials. It is a record of the conviction that photogrammetry was, in fact, the land surveying technique of the future and that, in spite of a variety of practical difficulties, it would indeed improve and facilitate survey work. At the same time, however, it had not yet been determined what exactly photogrammetry would be. Vergangene Zukunft points to a moment in the past when many possible future histories still existed. Paganini and his colleagues were convinced they were working on making one of these histories happen-but the promise of photogrammetry, like perhaps of every other technique, was also that its future applications were not completely foreseeable. Stereo photogrammetry, aerial mapping, and satellite reconnaissance-none of these were conceivable by the late $19^{\text {th }}$ century. In retrospect, however, they are possible outcomes, all of which were already contained-as potentials-in Paganini's panorama of 1878 .

36. Reinhart Koselleck, Vergangene Zukunft. Zur Semantik geschichtlicher Zeiten, Frankfurt, Suhrkamp, 1979. 
